\title{
Evaluation of Teacher's Attitudes Related to the Place-Based Education Approach Applied in Social Studies Lessons
}

\author{
Tuğba Cevriye Özkaral ${ }^{1} \&$ Ayşe Mentiş Taş ${ }^{1}$ \\ ${ }^{1}$ Necmettin Erbakan University, Turkey. \\ Correspondence: Tuğba Cevriye Özkaral, Necmettin Erbakan University, Turkey. \\ Received: July 18, 2018 \\ Accepted: August 17, 2018 \\ Online Published: August 21, 2018 \\ doi:10.5430/ijhe.v7n4p166 \\ URL: https://doi.org/10.5430/ijhe.v7n4p166
}

\begin{abstract}
The objective of this research is to evaluate the class and social studies teachers' attitudes on the place-based education approach applied in social studies lesson. The research is carried out using a survey model. In the research, a scale was developed to evaluate teachers' attitudes about "Place-Based Education" approach and activities applied in social studies lessons. After the necessary permissions taken from the Ministry of National Education, the scale was applied to 212 teachers. There was no significant difference between class and social sciences teachers' attitudes towards place based education approach for gender, branch, educational background, years of service and in-service training variables.
\end{abstract}

Keywords: social studies, place-based education, attitude

\section{Introduction}

From past to present, we can see that solely with theoretical knowledge are not efficient. Approaches that make students active, that ensure strong ties to the place they live and that help them solve local problems are needed. Place based education is one of these approaches.

Every society wants to cultivate citizens who are devoted to where they live. In this respect, one of the most important responsibilities of educational institutions and educators is to develop place loyalty and to create place awareness in students by planning and realizing activities that enable students to have opportunities to improve their relations with nature and society in the place they live. Place based education which is an effective approach to create place loyalty and place awareness, provides opportunities for educational institutions to fulfill their responsibilities (Kosker, 2012). David Sobel is one of the forerunners of the place based education approach and gives important information about this approach. According to Sobel (2004), place based education is a process of using the local community and environment as a starting point in order to teach notions in the field of language arts, mathematics, social studies, science and others.

Although place based education approach is popular in recent years in Turkey, the concept has been used in the early 18th century. Place based education, also defined as an out-of-school experience, is an educational approach with geographical, artistic, literary, scientific and historical aspects. Since place based education brings the basic characteristics of the society to the classroom environment, it provides positive contributions in increasing the interest of the students to the classes, improving the responsibilities of citizenship, increasing the student success in all courses, especially in the social studies lessons (Evans and Kilinç, 2013).In this direction, it is observed that the descriptions of the place based education are given in many elements of current social studies curriculum in Turkey. In particular, it is aimed to identify environment and interaction of the people with "People, Places and Circles" learning areas, to understand the causes and consequences of this interaction using a variety of skills and values and to to gain an individual or social point of view towards the future. The program also emphasizes the importance of utilizing social settings in non-school settings. These studies may be directed from the neighborhood of the school (such as school garden) to the marketplace, the official offices, factories, exhibitions, archaeological excavation sites, workshops, museums and historical sites (historical buildings, monuments, museum-cities, battlefields, virtual museum trips etc.) (MEB, 2017).

An example of place based educational activities by Roberts (2013) is as follows: They go to a theater and write a review of the spectacle. They go to the beach and write a poem or a creative writing that tells what they had experienced there. They go to the art gallery and discuss or write about their thoughts as a couple or as a group, why 
their favorite pictures are better than others. They go to the state library and benefit from resources to do homework. They go to a university and attend a class that attacks them (under the guidance of an instructor). While studying on a war, peace, migration, racism or religion subject, students may go to a Christian church or Muslim mosque to learn similarities and differences.

Place based education benefits include (Fly, 2010):
* Increasing academic performance
* Greater harmony and relationship between students and teachers
* More motivated students
* Less absenteeism
* Decreasing behavioral problems
* Spending time in society and outer spaces
* Decreasing obesity, diabetes and vitamin D deficiency under favor of physical activities that enhance the health

* Decreasing Attention Deficit Disorder with Hyperactivity (ADHD) symptoms

Most importantly, thanks to place based outdoor education, learning is more amusing. Becoming permanent of this situation in education will provide permanent learning at the same time. Hence, the adoption and implementation of place based education and similar approaches by teachers are of great importance for education. In this context, teachers' attitudes related to contemporary approaches should be evaluated.

Objective

The objective of this research is to evaluate the class and social studies teachers' attitudes on the place-based education approach applied in social studies lesson.

\subsection{Sub-Goals}

The sub-goals of the research are the following questions:

$>$ Are attitudes of class and social studies teachers differing significantly according to their gender in terms of place based education approach?

$>\quad$ Are attitudes of class and social studies teachers differing significantly according to their branch in terms of place based education approach?

$>$ Are attitudes of class and social studies teachers differing significantly according to their educational background in terms of place based education approach?

$>$ Are attitudes of class and social studies teachers differing significantly according to their professional time in terms of place based education approach?

$>$ Are attitudes of class and social studies teachers differing significantly according to their in-service training activities in terms of place based education approach?

\subsection{The Importance of the Research}

When the literature review is conducted, it is determined that researches related to place based education approaches in Turkey are very few (Mentis Tas and Ozkaral, 2015; Kosker, 2012; Kosker and Karabag, 2012; Yildiz and Mentis Tas, 2015; Yildiz Yilmaz and Tabaru, 2017).Determining the attitudes of social studies teachers related to the place based educational approach which can be applied in language arts, mathematics and science and filling the gap related to the place based education approach in the literature indicate the importance of the study.

\subsection{Limitations}

1. The universe of the research is limited with class and social studies teachers working in primary and secondary schools in the central districts of Konya province.

2. The "attitudes towards the place based education approach" which is one of the dependent variables of the research is limited to the features measured with the "Teacher Attitude Scale on the Place-Based Educational Approach Applied in the Social Studies Lesson", which is a study of validity and reliability and developed by researchers. 


\section{Method}

\subsection{Research Model}

The research was conducted using the relational screening model. Screening is a research model that aims to identify the past or present situation as it exists. The event, individual or object subjected to the research is tried to be defined as if it is within its own conditions. There is no effort to change them in any way, and there is something to be known (Karasar, 2016).

\subsection{Population and Sample}

The scope of the research constitutes class and social studies teachers working in primary and secondary schools affiliated to the Ministry of National Education in Meram, Selçuklu and Karatay which are the central districts of Konya province. In establishing the sample, firstly, schools were identified. The schools included in the scope of the research were determined by random sampling method from these schools. After the necessary permissions taken from the Ministry of National Education, the scale was applied to 212 teachers.

\subsection{Development of the Assessment Instrument}

While the scale was being created, the literature was first reviewed and a item pool was formed within the framework of the subject boundaries. Expert opinions were obtained from 5 faculty members who work in Nigde Omer Halisdemir University, Ahi Evran University, Nevsehir University, Faculty of Education University of Adiyaman University.4 of the experts are relevant area experts and 1 is a measurement and evaluation specialist. Revising has been made in the accordance with expert opinions. A scale on a trial basis consisting of 45 items was carried out. Trial of the scale applied to teachers who are selected by simple random sampling way and who give social studies lessons situated in Selçuklu, Meram and Karatay central districts of Konya.

\subsection{The Validity and Reliability of the Assessment Instrument}

Before revealing the factor structure of the scale, item-total correlations were examined and items 9,10,18,22,23,32, and 39, which had negative item-total correlations, were not included in the analysis. The Exploratory Factor Analysis was conducted on 38 items in order to reveal the factor structure of the scale.

Explanatory Factor Analysis (EFA) was utilized to provide evidence for the construct validity of the scale. In EFA, Principal Component Analysis was used as a factorization technique. Prior to interpreting the findings of the Principal Component Analysis, the results of the Kaiser-Meyer-Olkin (KMO) Test and the Barlett Test were considered whether the sample size was sufficient and whether the normality assumption was answered. As a result of the factor analysis, the KMO value was 0.888 . The value close to 1 indicates that the data structure is perfectly suitable for factor analysis in terms of sample size. Moreover, according to Bartlett's test for Sphericity result, Chi-squared $(\chi 2)$ value was found to be meaningfully 0.01 level $(\chi 2=6551.915, \mathrm{p}<.01)$.

As a result of the principal components analysis, findings of the factors were obtained. The varimax (maximum variability) method has been used as the perpendicular rotation method in order to determine which dimensions of the items are better positioned. The items with a factor load of at least 0.32 were selected for the original scale (Tabachnick and Fidel, 2001). Nine items with high load values in more than one factor were removed from the scale.

It was seen that the items were collected under three factors sufficiently separated from each other. Since the items in the first dimension are the items expressing the positive aspects of the activities outside the classroom, this dimension are called "Benefits of Place-Based Education". Since the items in the second dimension are items expressing the necessity of place based education, this dimension is called "Necessity of Place-Based Education". Since the items in the third dimension are items expressing the difficulties of out-of-class activities, this dimension is called "Difficulties of Place-Based Education".

As a result of trial application, an attitude scale consisting of 28 items and three sub-dimensions was obtained. 21 items of attitude scale items are positive and 7 items are negative. While factor load values of the items in the first dimension range between $0.580-0.763$, factor load values of the items in the second dimension range between $0.679-0.827$, and factor load values of the items in the third dimension range between 0.534-0.655. The first dimension describes $36,620 \%$ of the variance, the second $10,660 \%$ and the third dimension $6,246 \%$. The three dimensions describes $53,706 \%$ of the total variance.

In order to test the reliability, the Cronbach alpha internal consistency coefficient, and the item-total correlation (item discrimination values) which measure the consistency of items with each other and the entire test, are calculated. The item-total correlations (item discrimination values) explaining the relationship between the scores from the scale 
items and the total score of the scale are between 0.556 and 0.648 in the first dimension; between 0.679 and 0.772 in the second dimension and between 0.333 and 0.637 in the third dimension. All of these calculated item-total correlation values are significant at 0.01 level. These results were interpreted as the fact that the validity of the items in the scale is adequate, that students distinguished in terms of attitudes and were the items to measure the same behavior.

To determine the reliability of the scale, the Cronbach's alpha reliability coefficient was calculated. As a result of the reliability analysis, the reliability of the first sub-dimension was 0.925 , the second sub-dimension was 0.919 , and the third sub-dimension was 0.771 . The reliability coefficient for the complete scale was 0.912 . The calculated reliability coefficients show that each sub-dimension and the whole of the scale have high reliability, so that the items can be measured in a way that is consistent with each other.

\subsection{Data Collection Tool}

The first part of the scale, which is developed as a data collection tool, comprises instructions, the second part comprises the personal information and the third part comprises the expressions and response options. In the instructions, the purpose of the scale includes information concerning the total number of expressions, the format of the response and place based education approach. On the Personal Information Form, information such as the teacher's gender, branch, educational background, professional time, and in-service training regarding the place based educational approach are included. In the section on expressions and response options, there are expressions that will enable us to determine attitudes of teachers who teach social science classes towards the place-based education approach and the corresponding response options to these expressions.

The scale developed by the researchers consists of 28 items and 3 sub-dimensions:

1. Necessity of Place-Based Education: consists of 8 items. These items are 1, 2, 3, 4, 5, 6, 7, 8

2. Difficulties of Place-Based Education: consists of 7 items. These items are 9, 10, 12, 13, 14, 26,27 (negative items)

2. Benefits of Place Based Education: consists of 13 items. These items are 11, 15, 16, 17, 19, 20, 21, 22, 23, 24, 25, 28,29

The scale consisting of 28 items about the above 3 dimensions is in 5 point likert type with the options "Strongly disagree (1), Disagree (2), Partially agree (3), Agree (4), and Strongly agree (5)".

\subsection{Collection of Data}

In the spring semester of 2016-2017 academic year, the scales used as data collection instruments after the permission taken from Konya Directorate of National Education were applied to the class and social studies teachers in the sample. The following steps were followed while collecting research data: The work density of the teachers was taken into consideration and appropriate times to them were taken into account. Scales were given to teachers included in the sampling by the researchers. After all the scales were collected, the answers were checked. Incomplete ones were removed and other scales were taken into consideration.

\subsection{Data Analysis}

In the research, SPSS 20 package program is used in analysis of the data obtained from the developed scale to evaluate teachers' attitudes about "Place-Based Education" approach and activities applied in social studies lessons.

Before the analysis of the data, it was determined whether the hypothesis of normality was met. For this purpose, Kolmogorov Smirnov Test results are examined.

Table 1. Kolmogrov Smirnov Test Results

\begin{tabular}{llll}
\hline & \multicolumn{3}{l}{ Kolmogorov-Smirnov } \\
\cline { 2 - 4 } & Statistic & Sd & $\mathrm{P}$ \\
\hline Necessity &, 190 & 212 &, 000 \\
Difficulty &, 091 & 212 &, 000 \\
Benefit &, 074 & 212 &, 007 \\
Attitude &, 110 & 212 &, 000 \\
\hline
\end{tabular}

When Table 1 is examined, it is seen that the scores related to both the sub-dimensions and the scale show deviation from the normal distribution $(\mathrm{p}<0,05)$. For this reason, non-parametric methods have been used in the analysis of 
data. For this reason, nonparametric methods have been used in the analysis of data. Since the obtained data were not normally distributed, the Kruskall-Wallis $\mathrm{H}$ test was used to compare three and more group comparisons and the Mann-Whitney U test for two-group comparisons.

Table 2. Ranges

\begin{tabular}{lll}
\hline & Range & Level \\
\hline Necessity of place-based education & $8 \leq \bar{X} \leq 14.4$ & Strongly disagree \\
& $14.4<\bar{X} \leq 20.8$ & Disagree \\
& $20.8<\bar{X} \leq 27.2$ & Partially agree \\
& $27.2<\bar{X} \leq 33.6$ & Agree \\
& $33.6<\bar{X} \leq 40$ & Strongly agree \\
Difficulties of place-based & $7 \leq \bar{X} \leq 12.6$ & Strongly disagree \\
education & $12.6<\bar{X} \leq 18.2$ & Disagree \\
& $18.2<\bar{X} \leq 23.8$ & Partially agree \\
& $23.8<\bar{X} \leq 29.4$ & Agree \\
& $29.4<\bar{X} \leq 35$ & Strongly agree \\
Benefits of Place-Based Education & $13 \leq \bar{X} \leq 23.4$ & Strongly disagree \\
& $23.4<\bar{X} \leq 33.8$ & Disagree \\
& $33.8<\bar{X} \leq 44.2$ & Partially agree \\
& $44.2<\bar{X} \leq 54.6$ & Agree \\
& $54.6<\bar{X} \leq 65$ & Strongly agree \\
Total & $28 \leq \bar{X} \leq 50.4$ & Strongly disagree \\
& $50.4<\bar{X} \leq 72.8$ & Disagree \\
& $72.8<\bar{X} \leq 95.2$ & Partially agree \\
& $95.2<\bar{X} \leq 117.6$ & Agree \\
& $117.6<\bar{X} \leq 140$ & Strongly agree \\
\hline
\end{tabular}

Table 3. Descriptive Statistics

\begin{tabular}{lcllllll}
\hline & $\bar{X}$ & $\begin{array}{l}\text { Std. } \\
\text { Deviation }\end{array}$ & $\begin{array}{l}\text { Minimum } \\
\text { value }\end{array}$ & $\begin{array}{l}\text { Maximum } \\
\text { Value }\end{array}$ & Skewness & Kurtosis & Level \\
\hline Necessity & 34,65 & 6,07 & 8,00 & 40,00 & $-2,204$ & 6,434 & Strongly agree \\
Difficulty & 23,20 & 5,31 & 7,00 & 35,00 &,- 212 &, 416 & Partially agree \\
Benefit & 50,66 & 6,35 & 21,00 & 61,00 &,- 995 & 2,923 & Agree \\
Attitude & 108,52 & 13,58 & 45,00 & 136,00 & $-1,307$ & 4,137 & Agree \\
\hline
\end{tabular}

Averages of teachers' scores on the necessity dimension $\bar{X}=34,65$; on the difficulty dimension. $\quad \bar{X}=23,20$; on the benefit dimension $\bar{X}=50,66$ and place based attitude scores $\bar{X}=108,52$. It is seem that teachers have opinions "strongly agree" on necessity dimension, "partially agree" on difficulty dimension and "agree" on benefit dimension.

\section{Findings and Comments}

Table 4. Mann Whitney U test results according to gender

\begin{tabular}{lllllclll}
\hline Attitude & Gender & $\mathrm{N}$ & $\bar{X}$ & Level & Mean Rank & Rank Sum & U \\
\hline necessity & Female & 93 & 34,27 & Strongly agree & 105,72 & 9832,00 & 5461,000 &, 869 \\
& Male & 119 & 34,98 & Strongly agree & 107,11 & 12746,00 & & \\
\multirow{2}{*}{ Difficulty } & Female & 93 & 22,83 & Partially agree & 102,69 & 9550,00 & 5179,000 &, 422 \\
& Male & 119 & 23,49 & Partially agree & 109,48 & 13028,00 & & \\
Benefit & Female & 93 & 50,00 & Agree & 100,60 & 9355,50 & 4984,000 &, 215 \\
& Male & 119 & 51,19 & Agree & 111,11 & 13222,50 & & \\
\multirow{2}{*}{ Total } & Female & 93 & 107,10 & Agree & 101,36 & 9426,50 & 5056,500 &, 281 \\
& Male & 119 & 109,63 & Agree & 110,52 & 13151,50 & & \\
\hline
\end{tabular}


Average of female teachers' scores related to the necessity sub-dimension $\bar{X}=34,27$; average of male teachers' scores $\bar{X}=34,98$. It is seen that both male and female teachers' attitudes towards the necessity sub-dimension are in the level of "strongly agree" and therefore they are in the positive direction. When Table 4 is examined, it is seen that although the attitudes of the male teachers to the necessity sub-dimension are higher than the female teachers, these differences are not significant $(p>0,05)$.

Averages of female teachers' scores on the difficulty sub-dimension $\bar{X}=22,83$; averages of male teachers' scores on the difficulty sub-dimension $\bar{X}=23,49$. The attitudes of male and female teachers on the difficulty sub-dimension are at the level of "Partialy agree". When Table 4 is examined, it is seen that although the attitudes of the male teachers towards the difficulty sub-dimension are higher than the female teachers, these differences are not significant $(\mathrm{p}>0,05)$.

Average of female teachers' scores on the benefit sub-dimension $\bar{X}=22,83$; average of male teachers' scores on the benefit sub-dimension $\bar{X}=23,49$. Both male and female teachers' attitudes towards the benefit sub-dimension are in the "agree" level, which is therefore seen as positive. When Table 4 is examined, it is seen that although the attitudes of the male teachers towards the benefit sub-dimension are higher than the female teachers, these differences are not significant $(\mathrm{p}>0,05)$.

Average of female teachers' scores on place based education $\bar{X}=107,10$; average of male teachers' scores on place based education $\bar{X}=109,63$. The attitudes of both male and female teachers on place-based education are in "agree" level, which is therefore seen as positive. When Table 4 is examined, it is seen that although the place-based education attitudes of male teachers are higher than that of female teachers, these differences are not significant ( $p$ > $0,05)$.

Table 5. Mann Whitney U Test Results according to branch

\begin{tabular}{lllllllll}
\hline Attitude & Branch & $\mathrm{N}$ & $\bar{X}$ & Level & Mean Rank & Rank Sum & U & P \\
\hline Necessity & Class & 164 & 34,76 & Strongly agree & 106,89 & 17530,50 & 3871,500 &, 862 \\
& Social & 48 & 34,35 & Strongly agree & 105,16 & 5047,50 & & \\
Difficulty & Class & 164 & 23,49 & Partially agree & 109,77 & 18002,50 & 3400,500 &, 150 \\
& Social & 48 & 22,21 & Partially agree & 95,32 & 4575,50 & & \\
Benefit & Class & 164 & 50,89 & Agree & 108,16 & 17738,50 & 3664,500 &, 465 \\
& Social & 48 & 49,85 & Agree & 100,82 & 4839,50 & & \\
Total & Class & 164 & 109,13 & Agree & 108,93 & 17864,50 & 3538,500 &, 286 \\
& Social & 48 & 106,42 & Agree & 98,20 & 4713,50 & & \\
& & & & & & & & \\
\end{tabular}

Average of class teachers' scores related to the necessity dimension $\bar{X}=34,76$; average of social studies teachers' scores related to the necessity dimension $\bar{X}=34,35$. Both class and social studies teachers seem to have a positive attitude because of their "strongly agree" attitude towards the necessity dimension. When Table 5 is examined, it is seen that although the attitudes of the class teachers on the necessity dimension are higher than the teachers of social studies, these differences are not significant ( $p>0,05)$.

Average of class teachers' scores related to difficulty dimension $\bar{X}=23,49$; social studies teachers' scores related to difficulty dimension $\bar{X}=22,21$. Class and social studies teachers' attitude towards the difficulty dimension seem to be at "partially agree" level. When Table 5 is examined, it is seen that although the attitudes of the class teachers on the difficulty dimension are higher than the teachers of social studies, these differences are not significant ( $p>0,05)$.

Average of class teachers' scores related to benefit dimension $\bar{X}=50,89$; social studies teachers' scores related to benefit dimension $\bar{X}=49,85$. Both class and social studies teachers seem to have a positive attitude because of their "agree" attitude towards the benefit dimension. When Table 5 is examined, it is seen that although the attitudes of the class teachers on the benefit dimension are higher than the teachers of social studies, these differences are not significant $(\mathrm{p}>0,05)$.

Average of class teachers' scores related to place based education $\bar{X}=109,13$; social studies teachers' scores related to place-based education $\bar{X}=106,42$. Both class and social studies teachers seem to have a positive attitude because of their "agree" attitude towards place-based education. When Table 5 is examined, it is seen that although the attitudes of the class teachers on place-based education are higher than the teachers of social studies, these differences are not significant ( $p>0,05)$. 
Table 6. Kruskal Wallis Test Results According to Educational Background

\begin{tabular}{|c|c|c|c|c|c|c|c|c|}
\hline Attitude & Education & $\mathrm{N}$ & $\bar{X}$ & Level & $\begin{array}{l}\text { Mean } \\
\text { Rank }\end{array}$ & $\chi^{2}$ & $\mathrm{p}$ & Significant Difference \\
\hline \multirow[t]{3}{*}{ Necessity } & $\begin{array}{l}\text { Associate } \\
\text { Degree }\end{array}$ & 24 & 37,29 & $\begin{array}{l}\text { Strongly } \\
\text { agree }\end{array}$ & 138,40 & \multirow[t]{3}{*}{8,359} & \multirow[t]{3}{*}{, $015^{*}$} & $\begin{array}{l}\text { Associate } \\
\text { Degree-Undergraduate }\end{array}$ \\
\hline & Undergraduate & 164 & 34,13 & $\begin{array}{l}\text { Strongly } \\
\text { agree }\end{array}$ & 100,80 & & & \\
\hline & $\begin{array}{l}\text { Graduate } \\
\text { Degree }\end{array}$ & 24 & 35,67 & $\begin{array}{l}\text { Strongly } \\
\text { agree }\end{array}$ & 113,58 & & & \\
\hline \multirow[t]{3}{*}{ Difficulty } & $\begin{array}{l}\text { Associate } \\
\text { Degree }\end{array}$ & 24 & 21,63 & $\begin{array}{l}\text { Partially } \\
\text { agree }\end{array}$ & 93,23 & \multirow[t]{3}{*}{1,292} & \multirow[t]{3}{*}{,524 } & \\
\hline & Undergraduate & 164 & 23,42 & $\begin{array}{l}\text { Partially } \\
\text { agree }\end{array}$ & 108,43 & & & \\
\hline & $\begin{array}{l}\text { Graduate } \\
\text { Degree }\end{array}$ & 24 & 23,29 & $\begin{array}{l}\text { Partially } \\
\text { agree }\end{array}$ & 106,60 & & & \\
\hline \multirow[t]{3}{*}{ Benefit } & $\begin{array}{l}\text { Associate } \\
\text { Degree }\end{array}$ & 24 & 52,88 & Agree & 127,50 & \multirow[t]{3}{*}{3,190} & \multirow[t]{3}{*}{,206 } & \\
\hline & Undergraduate & 164 & 50,32 & Agree & 103,67 & & & \\
\hline & $\begin{array}{l}\text { Graduate } \\
\text { Degree }\end{array}$ & 24 & 50,71 & Agree & 104,85 & & & \\
\hline \multirow[t]{3}{*}{ Total } & $\begin{array}{l}\text { Associate } \\
\text { Degree }\end{array}$ & 24 & 111,79 & Agree & 121,50 & \multirow[t]{3}{*}{2,089} & \multirow[t]{3}{*}{,352 } & \\
\hline & Undergraduate & 164 & 107,87 & Agree & 103,41 & & & \\
\hline & $\begin{array}{l}\text { Graduate } \\
\text { Degree }\end{array}$ & 24 & 109,67 & Agree & 109,23 & & & \\
\hline
\end{tabular}

$* \mathrm{p}<0,05$

The average of associate degree teachers' scores related to necessity dimension $\bar{X}=37,29$; average of undergraduate degree teachers' scores related to necessity dimension $\bar{X}=34.13$; average of graduate degree teachers' scores related to necessity dimension $\bar{X}=35,67$. Teachers with different levels of education seem to be positive to the place based education with "strongly agree" attitude level. When Table 6 is examined, it can be seen that there are significant differences between the attitude scores of the teachers on the necessity dimension according to the education level ( $p$ $<0.05$ ). When the results of the paired comparisons and the mean ranks are examined, it is seen that this difference is in favor of the associate degree teachers between the associate degree teachers and the undergraduate teachers.

The average of the scores of the associate degree teachers related to difficulty dimension $\bar{X}=21.63$; average of the scores of the undergraduate degree teachers $\bar{X}=23.42$; average of the scores of the graduate degree teachers $\bar{X}=$ 23,29 . It is observed that the attitude of teachers with associate degree, undergraduate and graduate degree are at the "Partially agree" level with regard to the difficulty dimension. When Table 6 is examined, it is seen that the attitude scores of the teachers about the difficulty dimension do not have any significant differences according to the educational background $(p>0,05)$.

The average of the scores of the associate degree teachers related to benefit dimension $\bar{X}=52,88$; average of the scores of the undergraduate degree teachers $\bar{X}=50,32$; average of the scores of the graduate degree teachers $\bar{X}=50,71$. It is observed positive as the attitude of teachers with associate degree, undergraduate and graduate degree are at the "agree" level with regard to the benefit dimension. When Table 6 is examined, it is seen that the attitude scores of the teachers about the benefit dimension do not have any significant differences according to the educational background $(\mathrm{p}>0,05)$.

The average of the scores of the associate degree teachers related to place based attitude $\bar{X}=111,79$; average of the scores of the undergraduate degree teachers $\bar{X}=107,87$; average of the scores of the graduate degree teachers $\bar{X}=109,67$. Teachers with different education backgrounds seem to be on the positive side, as their place based attitudes are at the "agree" level. When Table 6 is examined, it is seen that there is no significant difference between teachers' attitude scores related to place-based education compared to education level $\quad(p>0,05)$ 
Table 7. Kruskal Wallis Test Results according to Professional Time

\begin{tabular}{|c|c|c|c|c|c|c|c|}
\hline Attitude & Professional time & $\mathrm{N}$ & $\bar{X}$ & Level & Mean Rank & $\chi^{2}$ & $\mathrm{P}$ \\
\hline \multirow[t]{5}{*}{ Necessity } & $1-5$ years & 11 & 33,55 & Agree & 104,09 & 4,413 & ,353 \\
\hline & $6-10$ years & 31 & 35,36 & Strongly agree & 107,71 & & \\
\hline & $11-15$ years & 25 & 34,08 & Strongly agree & 93,74 & & \\
\hline & $16-20$ years & 49 & 34,25 & Strongly agree & 96,15 & & \\
\hline & 21 years and above & 96 & 34,94 & Strongly agree & 114,99 & & \\
\hline \multirow[t]{5}{*}{ Difficulty } & $1-5$ years & 11 & 24,55 & Agree & 118,64 & 5,216 & ,266 \\
\hline & $6-10$ years & 31 & 23,23 & Partially agree & 103,85 & & \\
\hline & $11-15$ years & 25 & 22,00 & Partially agree & 91,80 & & \\
\hline & $16-20$ years & 49 & 24,33 & Agree & 121,19 & & \\
\hline & 21 years and above & 96 & 22,77 & Partially agree & 102,29 & & \\
\hline \multirow[t]{5}{*}{ Benefit } & $1-5$ years & 11 & 47,73 & Agree & 93,23 & 3,347 &, 502 \\
\hline & $6-10$ years & 31 & 50,58 & Agree & 105,18 & & \\
\hline & $11-15$ years & 25 & 49,52 & Agree & 89,38 & & \\
\hline & $16-20$ years & 49 & 50,63 & Agree & 107,84 & & \\
\hline & 21 years and above & 96 & 51,32 & Agree & 112,22 & & \\
\hline \multirow[t]{5}{*}{ Total } & $1-5$ years & 11 & 105,82 & Agree & 105,50 & 3,670 & ,453 \\
\hline & $6-10$ years & 31 & 109,16 & Agree & 104,37 & & \\
\hline & $11-15$ years & 25 & 105,60 & Agree & 85,42 & & \\
\hline & $16-20$ years & 49 & 109,20 & Agree & 111,10 & & \\
\hline & 21 years and above & 96 & 109,03 & Agree & 110,44 & & \\
\hline
\end{tabular}

The average of the teachers' necessity sub-dimension scores for the professional time $1-5$ years $\bar{X}=33,55$; for the professional time 6-10 years $\bar{X}=35,36$; for the professional time $11-15$ years $\bar{X}=34,08$; for the professional time 16-20 years $\bar{X}=34,25$; for the professional time 21 years and above $\bar{X}=34,94$. The attitudes related to necessity sub-dimension for teachers with professional time 11-15 years are at the "agree" level, for others at "strongly agree" level, therefore it is observed as positive. When Table 7 is examined, it is seen that the attitude scores of the teachers on the necessity sub-dimension do not show any significant differences according to the professional time ( $\mathrm{p}>$ $0,05)$.

The average of the teachers' difficulty sub-dimension scores for the professional time $1-5$ years $\bar{X}=24,55$; for the professional time 6-10 years $\bar{X}=23,23$; for the professional time $11-15$ years $\bar{X}=22,00$; for the professional time $16-20$ years $\bar{X}=24,33$; for the professional time 21 years and above $\bar{X}=22,77$. It is seen that the attitudes of the teachers with the professional time 6-10, 11-15 years and 21 years and above, are at the level of "Partially agree" with regard to difficulty sub-dimension. Teachers with other professional time are on the "agree" level, therefore it seems to be positive. When Table 7 is examined, it is seen that the attitude scores of the teachers on the difficulty sub-dimension do not show any significant differences according to the professional time ( $p>0,05)$.

The average of the teachers' benefit sub-dimension scores for the professional time 1-5 years $\bar{X}=47,73$; for the professional time 6-10 years $\bar{X}=50,58$; for the professional time $11-15$ years $\bar{X}=49,52$; for the professional time 16-20 years $\bar{X}=50,63$; for the professional time 21 years and above $\bar{X}=51,32$. It is seen that the attitudes of the teachers with different years of professional time to the benefit sub-dimension are in the "agree" level and therefore are in the positive direction. When Table 7 is examined, it is seen that the attitude scores of the teachers on the benefit sub-dimension do not show any significant differences according to the professional time ( $p>0,05$ ).

The average of the teachers' place-based attitude sub-dimension scores for the professional time 1-5 years $\bar{X}=105,82$; for the professional time 6-10 years $\bar{X}=109,16$; for the professional time $11-15$ years $\bar{X}=105,60$; for the professional time 16-20 years $\bar{X}=109,20$; for the professional time 21 years and above $\bar{X}=109,03$. It is seen that the attitudes of the teachers with different years of professional time to the place-based education sub-dimension are in 
the "agree" level and therefore are in the positive direction. When Table 7 is examined, it is seen that the attitude scores of the teachers on the place-based education sub-dimension do not show any significant differences according to the professional time $(\mathrm{p}>0,05)$.

Table 8. Mann Whitney U Test Results According to In-service Training

\begin{tabular}{|c|c|c|c|c|c|c|c|c|c|}
\hline Attitude & In-service & Training & $\mathrm{N}$ & $\bar{X}$ & Level & Mean Rank & Rank Sum & $\mathrm{U}$ & $\mathrm{P}$ \\
\hline \multirow[t]{2}{*}{ Necessity } & Yes & & 45 & 34,58 & Strongly agree & 111,81 & 5031,50 & 3518,500 & ,510 \\
\hline & No & & 167 & 34,69 & Strongly agree & 105,07 & 17546,50 & & \\
\hline \multirow[t]{2}{*}{ Difficulty } & Yes & & 45 & 23,00 & Partially agree & 108,12 & 4865,50 & 3684,000 & 841 \\
\hline & No & & 167 & 23,25 & Partially agree & 106,06 & 17712,50 & & \\
\hline \multirow[t]{2}{*}{ Benefit } & Yes & & 45 & 50,98 & Agree & 117,41 & 5283,50 & 3266,500 & ,178 \\
\hline & No & & 167 & 50,57 & Agree & 103,56 & 17294,50 & & \\
\hline \multirow[t]{2}{*}{ Total } & Yes & & 45 & 108,56 & Agree & 114,51 & 5153,00 & 3397,000 & ,323 \\
\hline & No & & 167 & 108,51 & Agree & 104,34 & 17425,00 & & \\
\hline
\end{tabular}

The average of the scores regarding the necessity sub-dimension of the teachers with in-service training is $\bar{X}=34,58$; the average of the scores regarding the necessity sub-dimension of the teachers without in-service training is $\bar{X}=34,69$. It is seen that teachers' attitudes towards the necessity sub-dimension of both teachers with and without in-service training are in the "strongly agree" level and therefore are in the positive direction. When Table 8 is examined, it is seen that although the attitudes of teachers without in-service training are higher than those with in-service training regarding necessity sub-dimension, these differences are not significant $(p>0,05)$.

The average of the scores regarding the difficulty sub-dimension of the teachers with in-service training is $\bar{X}=23,00$; the average of the scores of the teachers without in-service training is $\bar{X}=23,25$. It is seen that teachers' attitudes towards the difficulty sub-dimension of teachers with and without in-service training are in the "partially agree" level. When Table 8 is examined, it is seen that although the attitudes of teachers without in-service training are higher than those with in-service training regarding difficulty sub-dimension, these differences are not significant $(p>0,05)$.

The average of the scores regarding the benefit sub-dimension of the teachers with in-service training is $\bar{X}=50,98$; the average of the scores of the teachers without in-service training is $\bar{X}=50,57$. It is seen that teachers' attitudes towards the benefit sub-dimension of both teachers with and without in-service training are in the "agree" level and therefore are in the positive direction. When Table 8 is examined, it is seen that although the attitudes of teachers with in-service training are higher than those without in-service training regarding benefit sub-dimension, these differences are not significant $(\mathrm{p}>0,05)$.

The average of the scores regarding the place-based education attitude of the teachers with in-service training is $\bar{X}=108,56$; the average of the scores of the teachers without in-service training is $\bar{X}=108,51$. It is seen that teachers' attitudes of both teachers with and without in-service training are in the "agree" level and therefore are in the positive direction. When Table 8 is examined, it is seen that although the attitudes of teachers without in-service training are higher than those with in-service training regarding place-based education, these differences are not significant ( $p$ > $0,05)$.

\section{Conclusion and Recommendations}

In this research, it was aimed to determine whether the attitudes of the class and social studies teachers regarding the place-based education approach differed significantly according to gender, branch, educational background, professional time and in-service training.

It is confirmed that there is no difference between the attitudes of teachers according to their genders regarding the place-based education approach. It is observed that both female and male teachers' attitudes towards the place-based educational approach are in the "agree" level and therefore are in the positive direction. Although the attitudes of male teachers were higher than those of female teachers, these differences were not significant.

It is confirmed that there is no difference between the attitudes of teachersaccording to their branches regarding the place based education approach. It is observed that both class and social studies teachers' attitudes towards the place based educational approach are in the "agree" level and therefore are in the positive direction. Although the attitudes of class teachers were higher than social studies teachers, these differences were not significant. 
It is confirmed that there is no difference between the attitudes of teachers according to their educational background regarding the place-based education approach. It is observed that attitudes of teachers with different educational background towards the place-based educational approach are in the "agree" level and therefore are in the positive direction. It is observed that there is no significant difference between teachers' place-based attitude scores according to their educational background. However, it is seen that there are significant differences among the attitude scores of the teachers regarding the necessity dimension according to the educational background ( $<<0,05)$. When the results of the paired comparisons and the mean ranks are examined, it is seen that this difference is in favor of the associate degree teachers between the associate degree teachers and the undergraduate teachers.

It is observed that there is no difference between teachers' place-based attitude scores according to their professional time. It is observed that attitudes of teachers with different professional time towards the place-based educational approach are in the "agree" level and therefore are in the positive direction. It is observed that there is no significant difference between teachers' place based attitude scores according to their professional time.

It is seen that there is no difference between teachers' place-based attitude scores according to their in-service training. It is observed that attitudes of teachers with and without in-service training towards the place-based educational approach are in the "agree" level and therefore are in the positive direction. Although the attitudes of teachers without in-service training were higher than teachers with in-service training, these differences were not significant.

According to these results, it can be said that the teachers who participated in the research have a positive attitude towards the place-based education. The teachers think that the place-based education is beneficial and necessary but it has difficulties in implementation. Based on this research, a second research can be conducted on teachers' place-based education practices. In particular, it is possible to study the extent to which place-based education is involved in education and the challenges they face.

\section{References}

EVANS, R. T.,KILINC, E. (2013). History of Place-Based Education in the Social Studies Field. Adíyaman University Journal of Social Sciences, 6(14), 263-280.

FLY, M. J. (2010). A Place-Based Model for K-12 Education in Tennessee. Department of Forestry, Wildlife, \& Fisheries College of Agriculture Sciences and Natural Resources The University of Tennessee - Knoxville, TN. http://web.utk.edu/ markfly/documents/

KOSKER, N. (2012). Teacher Opinions on Place Based Education Approach in Geography Education. Gazi University Educational Sciences Institute, Unpublished Doctorate Thesis, Ankara.

MEB. (2017). Social Studies Curriculum (Primary and Secondary School 4, 5, 6 and 7th Grades).

SOBEL, D. (2004). Place-based education: Connecting classrooms and communities. Barrington, MA: Orion Society.

KARASAR, N. (2016). Scientific Research Methods. Ankara: Nobel.

KOSKER, N., KARABAG, S. (2012). Teacher Opinions on Place Based Education Approach in Geography Education. Turkey Social Studies Journal, 16(3), 123-137.

MENTIS TAS, A. \& OZKARAL, T.C. (2015). Social Studies 4-5. Evaluation of Class Program and Course Books according to Place Based Education Approach. Bartin University Faculty of Education Journal XIV. International Participatory Class Teacher Training Symposium (21-23 May 2015) Special Issue, 32 - 43. https://doi.org/10.14686/BUEFAD.2015USOSOzelsayi13196

TABACHNICK, B. G., \& FIDELL, L. S. (2001). Using Multivariate Statistics. Boston: Allynand Bacon.

ROBERTS, B. (2013). Place-based Education in the English Curriculum. https://writingworks. wikispaces.com/Placebased+Education+in+the+English+Curriculum

YILDIZ, N. VE MENTIS TAS, A. (2015). Evaluation of Life Science 1st, 2nd and 3rd Grade Programs and Course Books in terms of Place Based Education. International Journal of Educational Science, 2(5), 273-284. https://doi.org/10.16991/INESJOURNAL.163

YILDIZ YILMAZ N. and TABARU, G. (2017). Evaluation of Science 3rd and 4rd Grade Programs and Course Books in terms of Place Based Education. Abant Izzet Baysal University Faculty of Education Journal, 17(3), 1584-1605. https://doi.org/10.17240/aibuefd.2017.17.31178-338849 